$\mathrm{NO}$ and $\mathrm{NO}_{2}$ emission

L. Horváth et al.

\title{
Nitric oxide and nitrous oxide emission from Hungarian forest soils; link with atmospheric $\mathrm{N}$-deposition
}

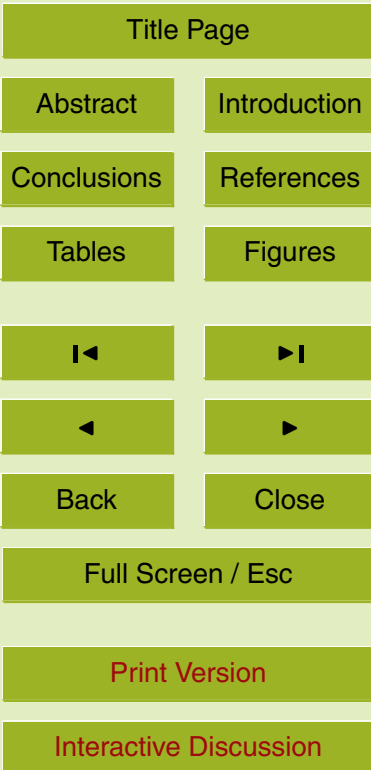

L. Horváth ${ }^{1}$, E. Führer ${ }^{2}$, and K. Lajtha ${ }^{3}$

${ }^{1}$ Department for Analysis of Atmospheric Environment, Hungarian Meteorological Service, Gilice tér 39, 1181 Budapest, Hungary

${ }^{2}$ Forest Research Institute, Frankel Leó u. 42-44, 1023, Budapest, Hungary

${ }^{3}$ Department of Botany and Plant Pathology, Oregon State University, Corvallis, Oregon, USA

Received: 2 May 2005 - Accepted: 14 June 2005 - Published: 24 June 2005

Interactive Discussion

Correspondence to: L. Horváth (horvath.I@ met.hu)

(C) 2005 Author(s). This work is licensed under a Creative Commons License. 


\section{Abstract}

Studies of forest nitrogen $(\mathrm{N})$ budgets generally measure inputs to the atmosphere in wet and dry precipitation and outputs via hydrologic export. Although denitrification has been shown to be important in many wetland ecosystems, emission of nitro5 gen oxides from forest soils is an important, and often overlooked, component of an ecosystem nitrogen budget. During one year (2002-2003), emissions of nitric oxide (NO) and nitrous oxide $\left(\mathrm{N}_{2} \mathrm{O}\right)$ were measured from Sessile oak and Norway spruce forest soils in northeast Hungary. Accumulation in small static chambers followed by gas chromatography-mass spectrometry detection was used for the estimation of $\mathrm{N}_{2} \mathrm{O}$ emission flux. Because there are rapid chemical reactions of $\mathrm{NO}$ and ozone, small dynamic chambers were used for in situ NO flux measurements. Average soil emissions of $\mathrm{NO}$ were 1.2 and $2.1 \mu \mathrm{g} \mathrm{N} \mathrm{m}^{-2} \mathrm{~h}^{-1}$, and for $\mathrm{N}_{2} \mathrm{O}$ were 15 and $20 \mu \mathrm{g} \mathrm{N} \mathrm{m}^{-2} \mathrm{~h}^{-1}$, for spruce and oak soils, respectively. The previously determined nitrogen balance between the atmosphere and the forest ecosystem was re-calculated using these soil emission figures. The total (dry + wet) atmospheric $\mathrm{N}$-deposition to the soil was 1.42 and $1.59 \mathrm{~g} \mathrm{~N} \mathrm{~m}^{-2} \mathrm{yr}^{-1}$ for spruce and oak, respectively, while the soil emissions are 0.14 and $0.20 \mathrm{~g} \mathrm{~N} \mathrm{~m}^{-2} \mathrm{yr}^{-1}$. Thus, about $10-13 \%$ of $\mathrm{N}$ compounds deposited to the soil, mostly as $\mathrm{NH}_{3} / \mathrm{NH}_{4}^{+}$and $\mathrm{HNO}_{3} / \mathrm{NO}_{3}^{-}$, are transformed in the soil and emitted back to the atmosphere, mostly as a greenhouse gas $\left(\mathrm{N}_{2} \mathrm{O}\right)$.

\section{Introduction}

Forest ecosystem $\mathrm{N}$ budgets have received considerable attention in recent years, in part due to increasing concern over increased $\mathrm{N}$ delivery to receiving waters from $\mathrm{N}$ saturated ecosystems (Aber et al., 1998; Dise et al., 1998; Pregitzer et al., 2004). In order to create predictive models of ecosystem and stream response to elevated $\mathrm{N}$ deposi-
$\mathrm{NO}$ and $\mathrm{NO}_{2}$ emission from Hungarian forest soils

L. Horváth et al.

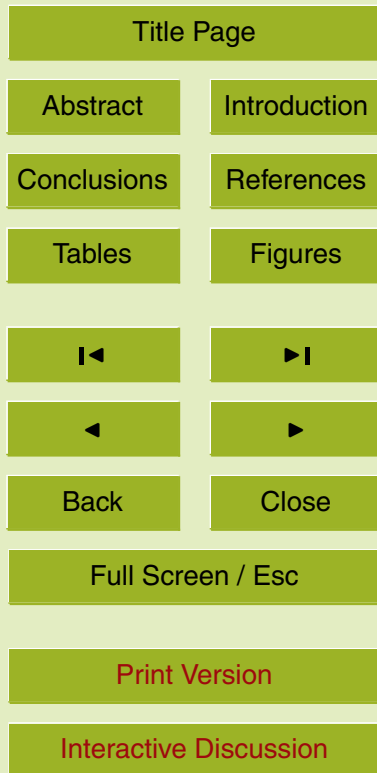

EGU 
denitrification processes in soils, and forest soil may be an important source for these compounds. Recent research has shown that the emission of $\mathrm{NO}$ and $\mathrm{N}_{2} \mathrm{O}$ depends, among other things, on forest type, soil characteristics, and on atmospheric deposition of $\mathrm{N}$ to the forest ecosystem (Groffman and Tiedje, 1989; Henrich and Haselwandter, 5 1997; Vermes and Myrold, 1992). In a cross-site study of 15 European forests sites (Pilegaard and NOFRETETE Team, 2004, 2005 ${ }^{1}$ ), the ratio of nitrogen oxide emission to $\mathrm{N}$-deposition ranged from very little up to $50 \%$. Although denitrification has shown to be insignificant in many forest ecosystems (e.g. Gundersen, 1991; Myrold at al., 1989), it is clear that in some forests, soils may contribute to the atmospheric $\mathrm{N}$-budget at both

10 a local and a global scale. As a large part of these $\mathrm{N}$ emissions may occur in the form of $\mathrm{N}_{2} \mathrm{O}$, such emissions have significant implications for global warming.

Field-based measurements of nitrogen oxide emissions from forested soils are limited. The aim of this work was to extend the forest soil nitrogen oxide emission network to Eastern Europe and provide data for its special climate, $\mathrm{N}$ deposition history, and 15 vegetation. This paper summarises the Hungarian contribution to the NOFRETETE objectives based on a one year long field study of nitrogen oxide emission from Sessile oak (Quercus petraea) and Norway spruce (Picea abies (L.) Karst.) forest soils in Hungary. A second objective was to compare the emission of nitrogen oxides form soils to the atmospheric $\mathrm{N}$ deposition fluxes, thus placing emissions into the context of the ecosystem $\mathrm{N}$ budget.

\section{Measurements}

\subsection{Field sites}

Both sites used in this study lie in the forested area of Mátra Mountains, NE Hungary, and are located in Ecology Research Stations of Forest Research Institute. Co-

\footnotetext{
${ }^{1}$ Pilegaard, K. and the NOFRETETE Team: Nitrogen load and forest type determine soil emission of nitrogen oxides ( $\mathrm{NO}$ and $\mathrm{N}_{2} \mathrm{O}$ ), Biogeosciences Discuss., submitted, 2005.
}

BGD

2, 703-723, 2005

$\mathrm{NO}$ and $\mathrm{NO}_{2}$ emission from Hungarian forest soils

L. Horváth et al.

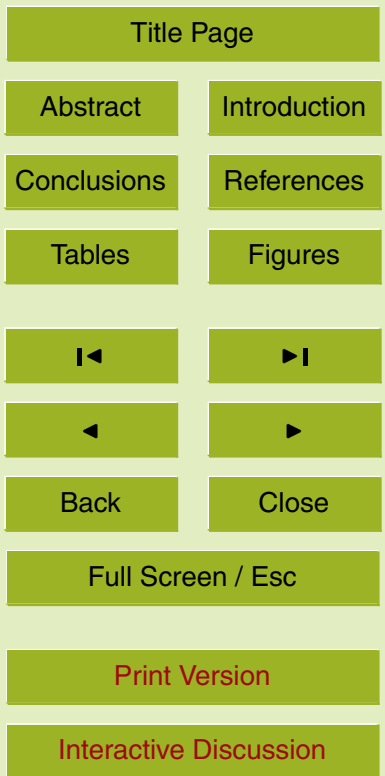

EGU 
ordinates of the 8 ha Norway spruce stand (Nyirjes) are: $\lambda=19^{\circ} 57^{\prime} 05^{\prime \prime}, \phi=47^{\circ} 53^{\prime} 38^{\prime \prime}$, $\mathrm{h}=560 \mathrm{~m}$. The age of the stand is 38-40 years, and leaf area index measured in 1993 is 3.3. Co-ordinates of the 20 ha Sessile oak stand (Tetves-rét) are: $\lambda=19^{\circ} 58^{\prime} 01^{\prime \prime}$, $\phi=47^{\circ} 51^{\prime} 56^{\prime \prime}, h=660 \mathrm{~m}$. The age of this stand is $71-76$ years, and leaf area index 5 was estimated as 4.0 . The distance between the two stands is $5 \mathrm{~km}$. Mean annual precipitation at both sites is $780 \mathrm{~mm}$, and mean annual temperature is $5.7^{\circ} \mathrm{C}$. The main characteristics of the stand and soil can be seen in Table 1.

\section{2. $\mathrm{N}_{2} \mathrm{O}$ soil emission flux measurements}

Nitrous oxide fluxes were determined by small static (closed) chambers following methods of Christensen et al. (1990). A total of 8-8 parallel chambers were used at both sites. Chambers were permanently placed approximately $3-4 \mathrm{~m}$ apart along a transect. The area and volume of the chambers are $80 \mathrm{~cm}^{2}$ and $400 \mathrm{~cm}^{3}$, respectively. After closure, gas samples were taken at $t=0,10,20$ and 30 min with a syringe. A total of $6 \mathrm{ml}$ of sample was injected into a $5.6 \mathrm{ml}$ evacuated tube. Accumulation of $\mathrm{N}_{2} \mathrm{O}$ was

15 measured by a gas chromatography-mass spectrometry system. Emission fluxes were calculated from the accumulation of nitrous oxide gas in the chamber. The calibration standard gas was $313 \mathrm{ppb} \mathrm{N}_{2} \mathrm{O}$ in $\mathrm{N}_{2}$, provided by NOAA, Environmental Monitoring and Diagnostics Laboratory. We sampled weekly except when soils were covered by snow. Pilot measurements for the spruce stand were taken June-August, 2002, and 20 regular measurements were taken October 2002-October 2003. We calculated the non-systematic error (coefficient of variation) of sampling and analysis with repeated sampling performed on one day at the two sites. The time difference between repeated samplings was $45 \mathrm{~min}$. Assuming that the emission flux from the soil was stable during this time, our bulk (sampling and analysis) error is approximately $10 \%$. Repeated GC25 MS analyses from samples of 3 October 2002 from the oak site resulted in 52.1 and $51.4 \mu \mathrm{g} \mathrm{N} \mathrm{m}^{-2} \mathrm{~h}^{-1}$ mean calculated flux. During a test run by sampling every minute, the coefficient of variation determined from the de-trended line was $11 \%$.

There is evidence for a systematic underestimation of soil gas flux using closed

$\mathrm{NO}$ and $\mathrm{NO}_{2}$ emission from Hungarian forest soils

L. Horváth et al.

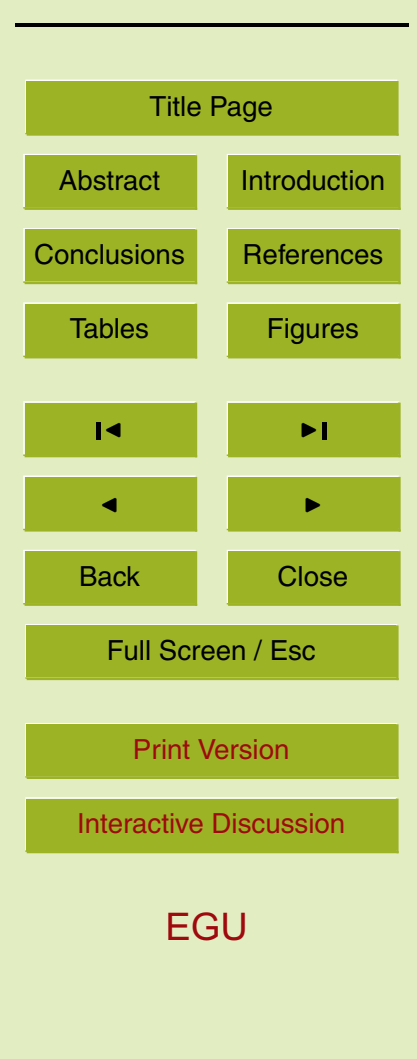


chambers. For carbon dioxide soil efflux, Rayment (2000) pointed out one bias caused by the fact that the effective volume of a chamber is larger than the physical chamber volume since it also includes the volume of air-filled spaces in the soil. This underestimation increases with a decrease in the height of the chamber. In our case $5 \quad(\mathrm{~h}=5 \mathrm{~cm})$, using Rayment's estimates for an equivalent depth of air in soil, soil fluxes are underestimated by $24 \%$. Conen and Smith (2000) predicted that $\mathrm{N}_{2} \mathrm{O}$ concentration increases in the soil air immediately after closure of the chamber due to high gas concentrations in the upper part of the soil profile. Christensen et al. (1996) compared 10 different closed, dynamic chambers and micro-meteorological methods and found 10 a good agreement between results. However, they also reported that the magnitude of underestimation is $20 \%$ using small chambers.

\subsection{NO soil emission flux measurements}

For the estimation of soil NO flux, small dynamic chambers were used with the same volume described above. A HORIBA gas monitor was used to detect the concentration 15 of NO leaving the chambers at both the spruce and oak sites. The ozone mixing ratio was simultaneously monitored. The calibration standard gas was $8 \mathrm{ppm} \mathrm{NO} / \mathrm{N}_{2}$. A Thermo Electron gas calibration system was used for multi-point calibration in the mixing ratio range of $0-10 \mathrm{ppb}$. The coefficient of variation determined for a calibration gas of $8 \mathrm{ppb}$ was $0.9 \%$. For soil samples with a mixing ratio of 1 and $10 \mathrm{ppb}$, the measured coefficients of variation were $5.3 \%$ and $1.5 \%$, respectively. Since the average mixing ratio found during the flux measurements lies between these two figures, our estimated coefficient of variation ranges between 1 and $5 \%$.

Ten minute concentration averages were recorded. Flow rate of the air through the dynamic chamber was $0.327 \mathrm{~L} \mathrm{~min}^{-1}$. The flux was calculated according to Meixner 25 (1997) as follows, taking into account the rapid chemical reaction of nitric oxide and ozone:

$\mathrm{NO}+\mathrm{O}_{3} \longrightarrow \mathrm{NO}_{2}+\mathrm{O}_{2}$
BGD

2, 703-723, 2005

$\mathrm{NO}$ and $\mathrm{NO}_{2}$ emission from Hungarian forest soils

L. Horváth et al.

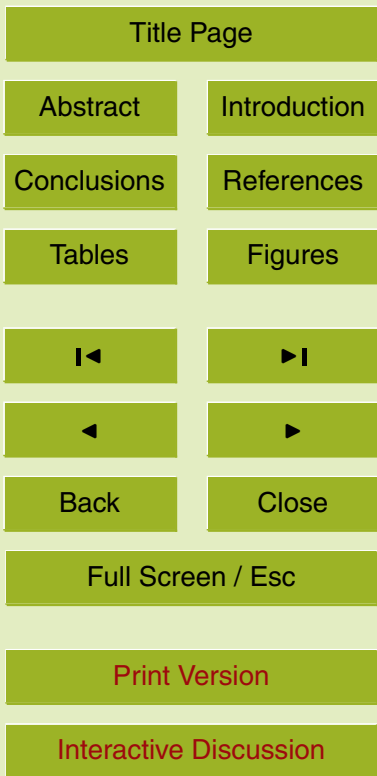

EGU 
The photolysis rate of $\mathrm{NO}_{2}$ inside the dark chambers was estimated to be zero. Under steady state conditions the mass balance equation for NO can be written as:

$F_{f}+F_{m}+F_{b l}+F_{g p}=0$,

where $F_{f}$ is the soil flux, $F_{m}$ is the difference between fluxes entering and leaving the 5 chamber, $F_{b /}$ is the term for the wall effect, and $F_{g p}$ is the loss of NO due to the chemical reaction with ozone. According to our measurements $F_{b /}$ is negligible because of the relatively short residence time ( $~ 80 \mathrm{~s}$ ) of the gas mixture in the chamber. The soil flux (in units of $\mu \mathrm{g} \mathrm{N} \mathrm{m}^{-2} \mathrm{~h}^{-1}$ ) can be calculated by the following equation where the two terms on the right represent the input and output fluxes from the chamber and the effect of the chemical reaction, respectively:

$F_{f}=\left\{[\mathrm{NO}]_{\text {out }}-[\mathrm{NO}]_{\text {in }}\right\} f_{1} f_{2} * Q / A+\left\{k[\mathrm{NO}]_{\text {out }}\left[\mathrm{O}_{3}\right]_{\text {out }}\right\} f_{1} * V / A$,

where $Q$ is the flow rate $\left(0.327^{*} 10^{-3} \mathrm{~m}^{3} \mathrm{~min}^{-1}\right), A$ is the surface of the soil covered by the chamber $\left[8^{*} 10^{-3} \mathrm{~m}^{2}\right],[\mathrm{NO}]_{\mathrm{out}}$ and $[\mathrm{NO}]_{\text {in }}$ are the $\mathrm{NO}$ mixing ratios leaving and entering the chamber [ppb], $f_{1}=14 / V_{t}, V_{t}$ is the molar volume at the given temperature $t\left[{ }^{\circ} \mathrm{C}\right]\left(V t=0.0795^{\star} t+22.41\right), f_{2}=60\left[\mathrm{~min}^{-1}\right]$ is the conversion term from minutes into hours, $V$ is the volume of the chamber, including tubing $\left(4.44^{*} 10^{-4} \mathrm{~m}^{3}\right), k$ is the reaction rate constant calculated as $k=1.8^{*} 10^{2} \exp (-1400 / T)\left[\mathrm{ppb}^{-1} \mathrm{~h}^{-1}\right]$ (Seinfeld and Pandis, 1998), where $T$ is the air temperature $[\mathrm{K}]$, and $\left[\mathrm{O}_{3}\right]_{\text {out }}$ is the mixing ratio of ozone (ppb) leaving the chamber. Because the latter term was not recorded, soil flux was calculated 20 first using $\left[\mathrm{O}_{3}\right]_{\text {out }}$ assuming that: $\left[\mathrm{O}_{3}\right]_{\text {in }} \approx\left[\mathrm{O}_{3}\right]_{\text {out }}$. This approximation is valid, if ozone is in excess of NO. In our case, the average mixing ratios of NO and ozone were 1.43 and $47.1 \mathrm{ppb}$, respectively, showing order of magnitude differences in the mixing ratios. However, in some cases the mixing ratio of $\mathrm{NO}$ was high and $\left[\mathrm{O}_{3}\right]_{\text {in }}>\left[\mathrm{O}_{3}\right]_{\text {out }}$. For this reason $\left[\mathrm{O}_{3}\right]_{\text {out }}$ was estimated from the following equation:

$\left[\mathrm{O}_{3}\right]_{\text {out }}=\left[\mathrm{O}_{3}\right]_{\text {in }}-\left\{[\mathrm{NO}]_{\text {out }}-[\mathrm{NO}]_{\text {in }}\right\} * F_{g p} / F_{m}=\left\{k[\mathrm{NO}]_{\text {out }}\left[\mathrm{O}_{3}\right]_{\text {out }}\right\} * V / Q f_{2}$,

which takes into account NO loss via reaction with ozone through the ratio of $F_{g p} / F_{m}$. From this equation the exact calculation of $\left[\mathrm{O}_{3}\right]_{\text {out }}$ is impossible, but through
$\mathrm{NO}$ and $\mathrm{NO}_{2}$ emission from Hungarian forest soils

L. Horváth et al.

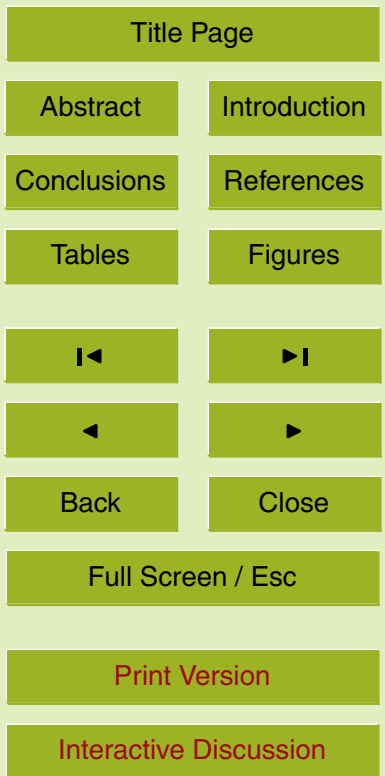

EGU 
iteration we are able to estimate the mixing ratio of ozone in the output air. First, $\left[\mathrm{O}_{3}\right]_{\text {out }}$ was calculated assuming $\left[\mathrm{O}_{3}\right]_{\text {in }} \approx\left[\mathrm{O}_{3}\right]_{\text {out }}$ for the calculation of $F_{g p}$. Then $F_{g p}$ was recalculated with the inferred $\left[\mathrm{O}_{3}\right]_{\text {out }}$. This process was repeated 5 times until there was no further change in the estimate of $\left[\mathrm{O}_{3}\right]_{\text {out }}$. The use of the correction for $\left[\mathrm{O}_{3}\right]_{\text {out }}$ gives 5 a lower value for the mean estimated soil fluxes by $10 \%$. The difference is much lower when the mixing ratio of $\mathrm{NO}$ is low. The variation in diurnal flux rate was checked by longer (approximately $24 \mathrm{~h}$ ) measurements. The signal was relatively stable for $20 \mathrm{~h}$, but a small decrease was observed at night.

At the spruce site, NO flux was measured once or twice a month. Flux rates were 10 determined 4 times at the oak site, and the magnitude of yearly mean flux was estimated using the ratio of fluxes in spruce and oak forest during the same period (in May, June, and September, 2003). The ratio of observed fluxes during these measurements was 1.744 . This factor was used to generate monthly values for NO flux in oak. This is a rough estimate, but the magnitude of $\mathrm{NO}$ flux (especially for the comparison to $\mathrm{N}_{2} \mathrm{O}$ ) 15 can be estimated this way.

Physical and chemical characteristics of the soil were measured in parallel with soil emission flux measurements. Soil temperature and moisture at three depths $(5,10$ and $20 \mathrm{~cm}$ ) has been recorded in the spruce stand since 1999 and since November, 2002 in the oak stand. Soil moisture data are available only at $20 \mathrm{~cm}$ at the spruce stand.

\subsection{Atmospheric $\mathrm{N}$ deposition}

For the estimation of total atmospheric $\mathrm{N}$-input to the canopy, dry deposition was inferred as $D D=C v$, where $C$ is the daily mean concentration measured in 2001-2003, $v$ is the mean dry deposition velocity in the different seasons, determined during earlier field trials. This estimate considered the net dry flux of ammonia $\left(\mathrm{NH}_{3}\right)$ and nitrogen 25 dioxide $\left(\mathrm{NO}_{2}\right)$ gases and nitric acid $\left(\mathrm{HNO}_{3}\right)$ vapour as well as the dry flux of ammonium $\left(\mathrm{NH}_{4}^{+}\right)$and nitrate $\left(\mathrm{NO}_{3}^{-}\right)$ions in aerosol particles.

Dry deposition velocity of $\mathrm{NO}_{2}$ gas was measured for three years (1996 and 1998) by the gradient method described in Horváth et al. $(1997,1998)$. Dry flux was calcu-

$\mathrm{NO}$ and $\mathrm{NO}_{2}$ emission from Hungarian forest soils

L. Horváth et al.

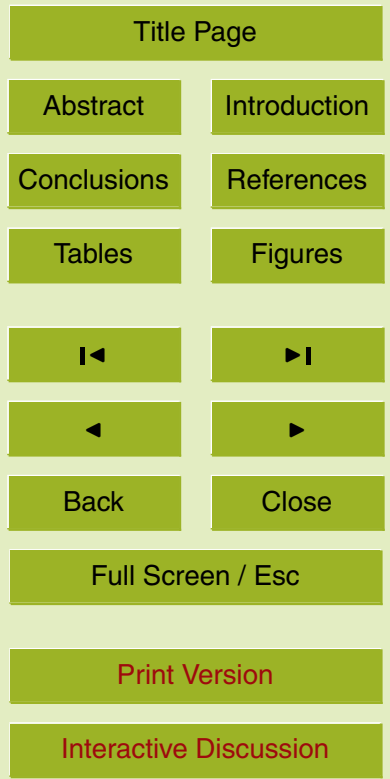

EGU 
lated as $F=-K_{H} d C / d z$, where $K_{H}$ is the turbulent diffusion coefficient for the sensible heat flux, $d C / d z$ is the concentration gradient. Concentration gradient was determined by concentration measurements at different heights $(28,23,18 \mathrm{~m})$ above the $16 \mathrm{~m}$ height canopy by a HORIBA APNA-350E $\mathrm{NO}_{x}$ gas monitor. Concentration averages 5 of 5 minute were logged at each level. Diffusion coefficients of gases were calculated according to the Monin-Obukhov's semi-empirical similarity theory (Weidinger et al., 2000) for stable and unstable stratification for the layer between 28 and $18 \mathrm{~m}$.

Concentration of ammonia, nitric acid and ammonium and nitrate particles were determined on the basis of 24-h sampling according to the EMEP (1996) filter pack 10 method. Ammonia gas and ammonium particles were measured as ammonium in the solution of sampling filters by indophenol-blue spectrophotometry. Nitric acid and nitrate particles were analysed by ion-chromatography. Dry deposition velocity was determined during an intensive campaign in 1998 (Horváth et al., 2001), using the gradient technique. Concentration gradient was determined by two filter pack samplers 15 settled at the height of 28 and $18 \mathrm{~m}$. Dry flux (DD) was calculated by the MoninObukhovs's similarity theory mentioned above. Mean dry deposition velocity was calculated as $v=D D / C$, where $C$ is the concentration at the upper height.

Wet, throughfall and stemflow deposition of nitrate and ammonium were also determined during 2001-2003. Wet deposition (WD) of nitrogen was determined as 20 tation, $p$ is the precipitation volume. Daily precipitation samples were taken by a wetonly collector out of the forest canopy. Ammonium and nitrate ions were determined by spectrophotometry and ion-chromatography, respectively.

Rain and snow samples were collected for throughfall by 5 collectors $\left(0.2 \mathrm{~m}^{2}\right.$ cross25

\section{flex} section area) randomly placed under the canopy in each stand, and for stemflow by flexible tubes attached to the trunk of 10 select trees in each stand. Details of sampling and measurement are described in Kovács and Horváth (2004) and Horváth (2004). At the spruce site, ozone concentrations are regularly recorded, and daily 24-h concentrations of $\mathrm{N}$ and $\mathrm{S}$ compounds are measured. There are various meteorological
BGD

2, 703-723, 2005

$\mathrm{NO}$ and $\mathrm{NO}_{2}$ emission from Hungarian forest soils

L. Horváth et al.

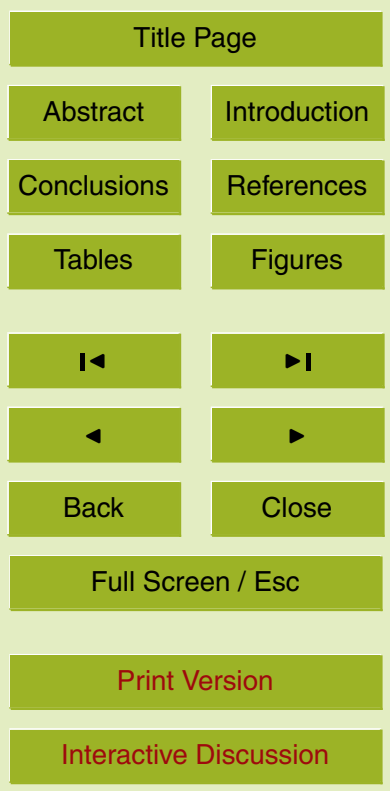

EGU 
and forestry measurements at the two sites (wind, air temperature, humidity, litter fall, forest growth, etc.).

The relation of wet $(W D)$, dry $(D D)$, throughfall $(T F)$, stemflow (SF) depositions can be expressed by the equation:

$5 W D+D D=T F+S F+N C E$,

where NCE denotes net canopy uptake, or the amount of deposited $\mathrm{N}$ taken up by the plant though stomata (Lovett and Lindberg 1993, Ferm and Hultberg, 1999).

\section{Results}

\section{1. $\mathrm{N}_{2} \mathrm{O}$ soil flux}

10 Soil $\mathrm{N}_{2} \mathrm{O}$ flux measured between October 2002 and October 2003 ranged from 0 to $70 \mu \mathrm{g} \mathrm{N} \mathrm{m}^{-2} \mathrm{~h}^{-1}$, depending on the season, with averages of 15 and $20 \mu \mathrm{g} \mathrm{N} \mathrm{m}^{-2} \mathrm{~h}^{-1}$ for spruce and oak, respectively (Fig. 1). Flux was not measured from the beginning of January until the end of March, 2003 due to snow. Yearly averages were calculated from the monthly means of 4-5 measurements per month assuming zero flux for the winter period with snow cover (Table 2). During this period soil temperature was close to $0^{\circ} \mathrm{C}$. There were weak positive correlations between $\mathrm{N}_{2} \mathrm{O}$ flux and soil temperature in both stands for all depths where soil temperature was recorded (Table 3 ). There were weak negative correlations between $\mathrm{N}_{2} \mathrm{O}$ flux and soil moisture, most significantly in the oak stand.

\subsection{NO soil flux}

NO flux was small compared to fluxes of $\mathrm{N}_{2} \mathrm{O}$ (Fig. 2). Significant soil NO flux was observed only during the summer. Average $\mathrm{NO}$ fluxes were 5.0 and $6.4 \mu \mathrm{g} \mathrm{N} \mathrm{m}^{-2} \mathrm{~h}^{-1}$ for spruce and oak, respectively. Correlation between emission rates of the two gases was calculated for the two sites when emission data were available $(n=20$; Table 3).

$\mathrm{NO}$ and $\mathrm{NO}_{2}$ emission from Hungarian forest soils

L. Horváth et al.

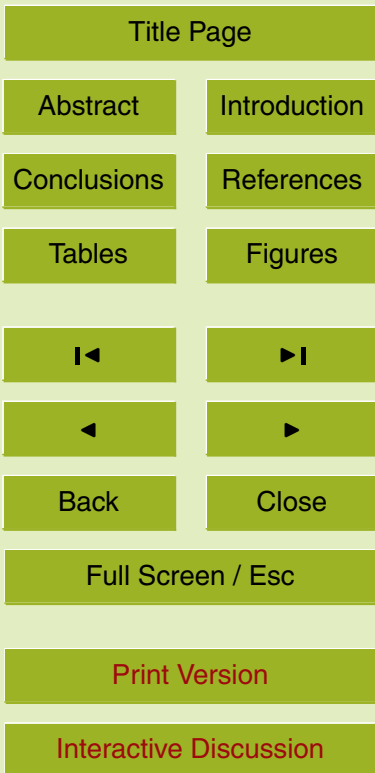

EGU 
The total atmospheric $\mathrm{N}$-deposition to the canopy, calculated as the sum of wet + dry deposition, was estimated as $1.7 \mathrm{~g} \mathrm{~N} \mathrm{~m}^{-2} \mathrm{yr}^{-1}$ (Horváth, 2004). Deposition to the soil was estimated from throughfall (TF) and stemflow (SF) measurements, and should 5 equal $\mathrm{N}$ deposition to the canopy minus net canopy exchange (NCE). NCE was calculated to be $16 \%$ of total $\mathrm{N}$ deposition to the spruce forest canopy, and $6.5 \%$ for the oak forest. Though litter fall deposition is much higher than other deposition forms, it represents the internal circulation of $\mathrm{N}$-compounds inside the canopy (Table 4). Emission of $\mathrm{NO}$ and $\mathrm{N}_{2} \mathrm{O}$ together returns $10-13 \%$ of the atmospheric deposition to the soil $10(T F+S F)$.

\section{Discussion}

Our results can be compared to those collected at 15 European forest sites as part of the EU-funded project NOFRETETE. The NOFRETETE locations represent different forest types (coniferous vs. deciduous) and span the typical nitrogen deposition rates found across Europe. In that survey (Pilegaard et al., 2005 ${ }^{1}$ ), NO emissions were much greater (ca. 8 times) from coniferous forests than from deciduous forests, and $\mathrm{N}_{2} \mathrm{O}$ emission rates were slightly lower (ca. 2/3) for coniferous forests. While the total $\left(\mathrm{NO}+\mathrm{N}_{2} \mathrm{O}\right.$ ) emissions are much higher for European coniferous forests, in the current study there were no significant differences between the spruce and oak sites for flux rates of either $\mathrm{NO}$ or $\mathrm{N}_{2} \mathrm{O}$, although the oak site had slightly higher mean flux rates. At our Hungarian coniferous site the total $\left(\mathrm{NO}+\mathrm{N}_{2} \mathrm{O}\right)$ mean soil emission is the half of the European average, and is roughly two times higher at our deciduous site compared to other European sites. This is a consequence of the depressed NO flux from our spruce soil and the enhanced $\mathrm{N}_{2} \mathrm{O}$ flux observed from the oak forest soil. Because NO is mainly derived from nitrification and $\mathrm{N}_{2} \mathrm{O}$ is mainly derived from denitrification, well aerated soils should favor the production of $\mathrm{NO}$ whereas the presence of anaerobic

\section{$\mathrm{NO}$ and $\mathrm{NO}_{2}$ emission from Hungarian forest soils}

L. Horváth et al.

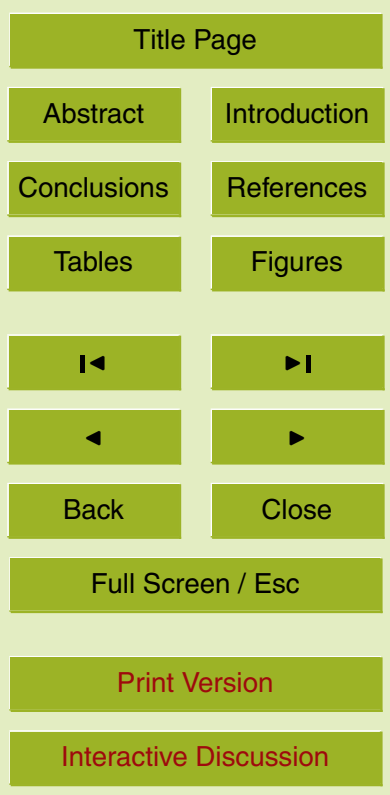

EGU 
microsites, due to thick litter layers or compaction, should favor $\mathrm{N}_{2} \mathrm{O}$ production. The lack of significant differences in flux rates from our two sites in this study might suggest that our soils are quite similar with respect to moisture regimes. It is also quite possible that the differences between conifer and deciduous sites observed in the larger survey 5 are due to factors other than tree species, i.e. the primary factors that caused forest stand differences in the first place, such as soil depth or temperature regime. Only further studies with paired conifer/deciduous stands can answer this question.

In our study, all gas flux rates were positively correlated with soil temperature and oak emission rates were negatively correlated with soil moisture. The positive correlation 10 with soil temperature is not surprising, as many indices of soil microbial activity, such as respiration, are positively related to temperature (Chen et al., 2000; Curiel Yuste et al., 2004; Franzluebbers et al., 2002; Sulzman et al., 2005). The negative correlation with soil moisture was surprising, as soil microbial processes are usually positively correlated with soil water, or other factors that control the supply of readily mineralizable 15 substrates (Qi and Xu, 2001; Franzluebbers et al., 2002). Only when soil moisture becomes too high does microbial respiration tend to decrease (Chen et al., 2000). This negative correlation suggests that our oak soils were wet enough that $\mathrm{N}_{2} \mathrm{O}$ production was decreasing, and perhaps $\mathrm{N}_{2}$ emissions from denitrification were increasing.

The estimate of canopy uptake by foliage in these two stands was $16 \%$ and $6.5 \%$ of total inorganic $\mathrm{N}$ deposition for the spruce and oak sites, respectively. This is quite low compared to results found for a variety of forests in the United States measured as part of the Integrated Forest Study (Lovett and Lindberg, 1993), where net canopy exchange was estimated to be about $40 \%$ of inorganic $\mathrm{N}$ deposition. These authors found a good correlation between NCE and total deposition, indicating that as deposition increases, $\mathrm{N}$ consumption in the canopy increases. There are many possible explanations for this discrepancy, including variations in methodology for measuring total $\mathrm{N}$ inputs. Alternatively, climatic differences and histories of $\mathrm{N}$ deposition to the sites may cause real differences in NCE among sites. The Hungarian forests in the current study have received chronic elevated $\mathrm{N}$ deposition for a longer period of time than
BGD

2, 703-723, 2005

$\mathrm{NO}$ and $\mathrm{NO}_{2}$ emission from Hungarian forest soils

L. Horváth et al.

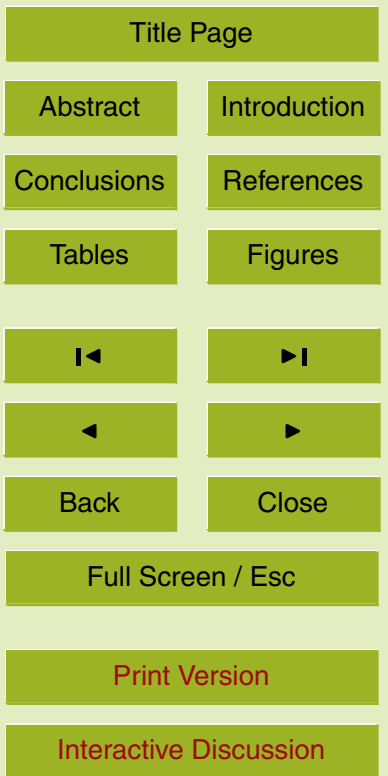

EGU 
have the US forests, and thus might be experiencing greater $\mathrm{N}$ saturation. Similarly, it is quite likely that chemical species of $\mathrm{N}$ in deposition, particularly in dry deposition, may be significantly different, and react differently on leaf surfaces. It is also possible that NCE is variable from year to year. An earlier (1996-1998) study of atmospheric fluxes 5 in these same forests (Horváth, 2004) measured higher $\mathrm{N}$ in wet deposition but lower $\mathrm{N}$ in throughfall and produced a higher estimate of $N C E$, more similar to estimates in the Lovett and Lindberg (1993) survey. Throughfall deposition has been shown to be quite variable both spatially and temporally, and only long-term studies can address the variability of true NCE.

10 Comparing $\mathrm{N}$ deposition numbers and gas efflux values, we found that factoring in $\mathrm{NO}$ and $\mathrm{N}_{2} \mathrm{O}$ emissions reduces the estimate of net $\mathrm{N}$ deposition to the canopy from $1.7 \mathrm{~g} \mathrm{~N} \mathrm{~m}^{-2} \mathrm{yr}^{-1}$ to $1.5-1.6 \mathrm{~g} \mathrm{~N} \mathrm{~m}^{-2} \mathrm{yr}^{-1}$, and thus does not affect this estimate significantly. We did not measure $\mathrm{N}_{2}$ emission from the soil, which can be significant especially at high moisture levels, and thus our estimates of $\mathrm{N}$ flux from the soil is an 15 underestimate. Still, fluxes of $\mathrm{NO}$ and $\mathrm{N}_{2} \mathrm{O}$ were found to be a measurable portion of $\mathrm{N}$ deposition to soil, which was estimated as 1.42 and $1.59 \mathrm{~g} \mathrm{~N} \mathrm{~m}^{-2} \mathrm{yr}^{-1}$ for spruce and oak, respectively, and thus these soil gas emissions are around $10-13 \%$ of the total atmospheric $\mathrm{N}$ deposition to the soil. It is also important to note that while deposition to the soil is mostly as $\mathrm{NH}_{3} / \mathrm{NH}_{4}^{+}$and $\mathrm{HNO}_{3} / \mathrm{NO}_{3}^{-}$, these compounds are transformed 20 in the soil and can be emitted as a greenhouse gas $\left(\mathrm{N}_{2} \mathrm{O}\right)$ back into the atmosphere. Thus, forest soils play a role in the transformation of deposited $\mathrm{N}$ compounds from regional or continental pollution sources into a greenhouse gas that acts at a global scale.

Acknowledgement. This research was coordinated and supported as part of the NOFRERETE 25 EU5th RTD project (project coordinator K. Butterbach-Bahl) by Forschungszentrum Karlsruhe Atmosphärische Umweltforschung IMK-IFU Garmisch-Partenkirchen, Germany through the contract with the Forest Research Institute Budapest, Hungary, contract reference number: 315/20228934/IMK-IFU.

\section{BGD}

2, 703-723, 2005

$\mathrm{NO}$ and $\mathrm{NO}_{2}$ emission from Hungarian forest soils

L. Horváth et al.

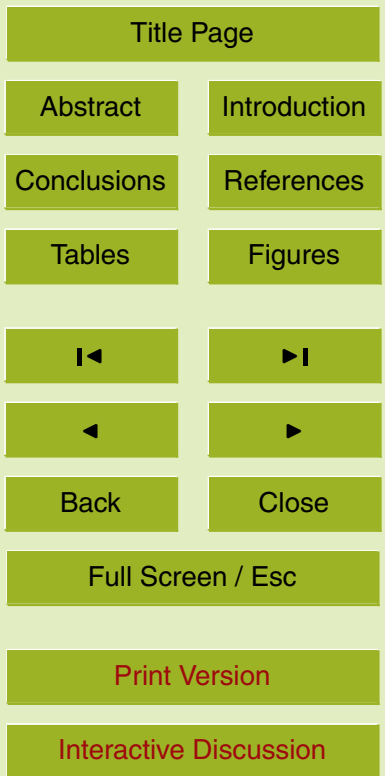

EGU 


\section{References}

Aber, J., McDowell, W., Nadelhoffer, K., Magill, A., Berntson, G., Kamakea, M., McNulty, S., Currie, W., Rustad, L., and Fernandez, I.: Nitrogen saturation in temperate forest ecosystems, BioScience, 48, 921-934, 1998.

5 Baron, J. S., Ojima, D. S., Holland, E. A., and Parton, W. J.: Analysis of nitrogen saturation potential in Rocky Mountain tundra and forest: implications for aquatic systems, Biogeochem., 27, 61-82, 1994.

Chen, H., Harmon, M. E., Griffiths, R. P., and Hicks, W.: Effects of temperature and moisture on carbon respired from decomposing woody roots, Forest Ecology and Management, 138,

$10 \quad 51-64,2000$.

Christensen, S., Simkins, S., and Tiedje, J.M.: Spatial variation in denitrification: Dependency of activity centers on the soil environment, Soil Sci. So., 54, 1608-1613, 1990.

Christensen, S., Ambus, P., Arah, J. R. M., Clayton, H., Galle, B., Griffith, D. W. T., Hargreaves, K. J., Klemedtsson, L., Lind, A.-M., Maag, M., Scot, A., Skiba, U., Smith, K. A., Welling, M., 15 and Wienhold, F. G.: Nitrous oxide emission from an agricultural field: comparison between measurements by flux chamber and micro-meteorological techniques, Atmos. Envir., 30, 4183-4190, 1996.

Conen, F. and Smith, A.: An explanation of linear increases in gas concentration under closed chambers used to measure gas exchange between soil and the atmosphere, Eur. J. So. Sc.,

$20 \quad 51,111-117,2000$.

Curiel Yuste, J., Janssens, I. A., Carrara, A., and Ceulemans, R.: Annual $Q_{10}$ of soil respiration reflects plant phenological patterns as well as temperature sensitivity, Global Change Biol., 10, 161-169, 2004.

Dise, N. B., Matzner, E., and Gundersen, P.: Synthesis of nitrogen pools and fluxes from European forest ecosystems, Water, Air, Soil Pollut., 105, 143-154, 1998.

EMEP: EMEP co-operative programme for monitoring and evaluation of the long-range transmission of air pollutants in Europe. EMEP Manual for sampling and chemical analysis, EMEP/CCC-Report 1/95, NILU, Kjeller, Norway, 1996.

Ferm, M. and Hultberg, H.: Dry deposition and internal circulation of nitrogen, sulphur and base cations into a coniferous forest, Atmos. Envir., 33, 4421-4430, 1999.

Franzluebbers, K., Franzluebbers, A. J., and Jawson, M. D.: Environmental controls on soil and whole-ecosystem respiration from a tallgrass prairie, Soil Sci. Soc. Am. J., 66, 254-262,
$\mathrm{NO}$ and $\mathrm{NO}_{2}$ emission from Hungarian forest soils

L. Horváth et al.

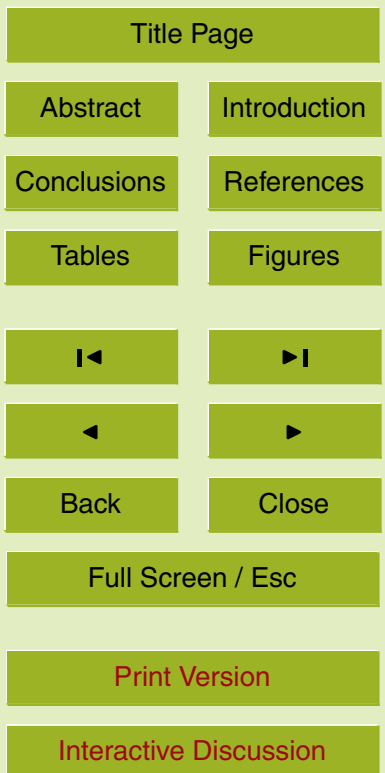

EGU 
2002.

Groffman, P. M. and Tiedje, J. M.: Denitrification in north temperate forest soils: relationships between denitrification and environmental factors at the landscape scale, Soil Biol. Biochem., 21, 621-626, 1989.

5 Gundersen, P.: Nitrogen deposition and the forest nitrogen cycle: role of denitrification, Forest Ecology and Management, 44, 15-28, 1991.

Henrich, M. and Haselwandter, K.: Denitrification and gaseous nitrogen losses from an acid spruce forest soil, Soil Biol. Biochem., 29, 1529-1537, 1997.

Horváth, L.: Determination of the nitrogen compound balance between the atmosphere and a Norway spruce forest ecosystem, Nutr. Cycl. A., 70, 143-146, 2004.

Horváth, L., Weidinger, T., Nagy, Z., and Führer, E.: Measurement of dry deposition velocity of ozone, sulfur dioxide and nitrogen oxides above Pine forest and low vegetation in different seasons by the gradient method, in: Proceedings of EUROTRAC Symposium '96 GarmischPartenkirchen, edited by: Borrell, P. M., Borrell, P., Cvitas, T., Kelly, K., and Seiler, W., Germany, 25-29 March 1996, Computational Mechanics Publications, Southampton, 315-318, 1997.

Horváth, L., Nagy, Z., and Weidinger, T.: Determination of the dry flux of ozone and sulfur dioxide during the TRACT campaign, Atmos. Environ., 32, 1317-1322, 1998.

Horváth, L., Mészáros, R., Pinto, J. P., and Weidinger, T.: Estimate of the dry deposition of atmospheric nitrogen and sulfur species to spruce forest, in: Proceedings of EUROTRAC Symposium 2000 Garmisch-Partenkirchen, edited by: Midgley, P. M., Reuther, M., and Williams, M., Germany, 27-31 March 2000, Springer-Verlag Berlin, Heidelberg, 2001.

Kovács, E. A. and Horváth. L.: Determination of sulfur balance between the atmosphere and a Norway spruce forest ecosystem: comparison of gradient dry + wet and throughfall deposition measurements, J. Atmos. Chem., 48, 235-240, 2004.

Lovett, G. M. and Lindberg, S. E.: Atmospheric deposition and canopy interactions of nitrogen in forests, Can. J. For. Res., 23, 1603-1616, 1993.

Meixner, F., Fickinger, Th., Marufu, L., Serca, D., Nathaus, F. J., Makina, E., Mukurumbira, L., and Andreae, M. O.: Preliminary results on nitric oxide emission from a southern African savanna ecosystem, Nutr. Cycl. A., 48, 123-138, 1997.

Myrold, D. D., Matson, P. A., and Peterson, D. L.: Relationships between soil microbial properties and aboveground stand characteristics of conifer forests in Oregon, Biogeochem., 8, 265-281, 1989.

$\mathrm{NO}$ and $\mathrm{NO}_{2}$ emission from Hungarian forest soils

L. Horváth et al.

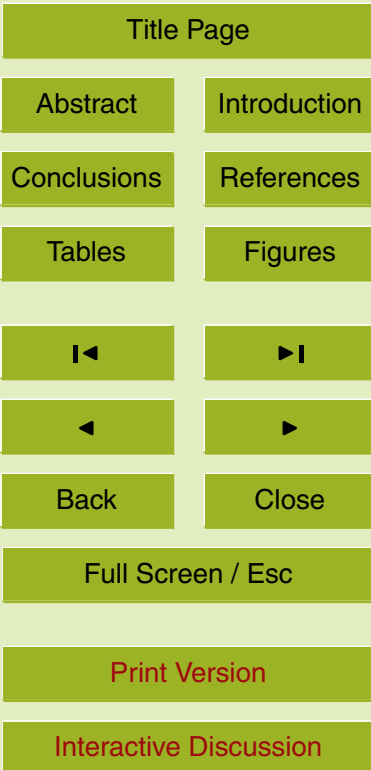

EGU 
Pilegaard, K. and the NOFRETETE Team: Nitrogen load and forest type determine soil emission of nitrogen oxides ( $\mathrm{NO}$ and $\mathrm{N}_{2} \mathrm{O}$ ), Geophys. Res. Abstr., 6, No. 05693, 2004.

Pregitzer, K. S., Zak, D. R., Burton, A. J., Ashby, J., and MacDonald, N. W.: Chronic nitrate additions dramatically increase the export of carbon and nitrogen from northern hardwood ecosystems, Biogeochem., 68, 179-197, 2004.

$\mathrm{Qi}, \mathrm{Y}$. and $\mathrm{Xu}, \mathrm{M}$.: Separating the effects of moisture and temperature on soil $\mathrm{CO}_{2}$ efflux in a coniferous forest in the Sierra Nevada mountains, Plant Soil, 237, 15-23, 2001.

Rayment, M. B.: Closed chamber systems underestimate soil $\mathrm{CO}_{2}$ efflux, Eur. J. So. Sc., 51, 107-110, 2000.

10 Seinfeld, J. H. and Pandis, S. N.: Atmospheric chemistry and physics: From air pollution to climatic change, John Wiley and Sons Inc., New York, Chichester, Weinheim, Brisbane, Singapore, Toronto, 1998.

Sulzman, E. W., Brant, J. B., Bowden, R. D., and Lajtha, K.: Contribution of aboveground litter, belowground litter, and rhizosphere respiration to total soil $\mathrm{CO}_{2}$ efflux in an old growth coniferous forest, Biogeochem., in press, 2005.

Vermes, J.-F. and Myrold, D. D.: Denitrification in forest soils of Oregon, Can. J. For. Res., 22, 504-512, 1992.

Weidinger, T., Pinto, J., and Horváth, L.: Effects of uncertainties in universal functions, roughness length, and displacement height on the calculation of surface layer fluxes, Meteorologische Zeitschrift 9, 139-154, 2000.

2, 703-723, 2005

$\mathrm{NO}$ and $\mathrm{NO}_{2}$ emission from Hungarian forest soils

L. Horváth et al.

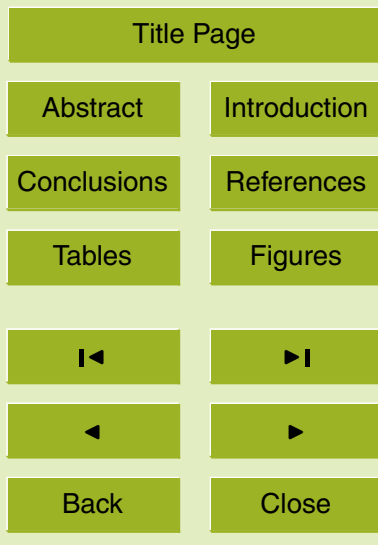

Full Screen / Esc

Print Version

Interactive Discussion 
Table 1. Stand and soil characteristics of the Norway spruce and Sessile oak stands used in this study (surveyed in 2000).

\begin{tabular}{llccc}
\hline & & spruce & oak \\
\hline Stand density & & trees ha & 1188 & 776 \\
Stand height & $\mathrm{m}$ & 20.1 & 20.5 \\
Mean breast diameter & & $\mathrm{cm}$ & 20.1 & 22 \\
Rooting depth & $\mathrm{m}$ & $>1$ & $>1$ \\
Soil type & & Eutric Leptosol & Mollic Leptosol \\
Organic layer type & & moder/mull & mull \\
Organic layer C stocks & humus layer & $\mathrm{g} \mathrm{k} \mathrm{kg}^{-1}$ & 236 & 144 \\
Organic layer N stocks & humus layer & $\mathrm{g} \mathrm{N} \mathrm{kg}^{-1}$ & 12 & 9.3 \\
Organic layer, C:N ratio & humus layer & & 19.7 & 15.4 \\
Organic layer, pH & humus layer & & 4.5 & 5.7 \\
Mineral soil, clay:silt:sand & $0-10 \mathrm{~cm}$ & $\%$ & $15: 29: 56$ & $17: 38: 45$ \\
Mineral soil, clay:silt:sand & $10-20 \mathrm{~cm}$ & $\%$ & $18: 31: 51$ & $20: 42: 38$ \\
Mineral soil, clay:silt:sand & $20-40 \mathrm{~cm}$ & $21: 26: 53$ & $25: 38: 37$ \\
Mineral soil, C stocks & $0-5,5-10,10-20,20-40 \mathrm{~cm}$ & $\mathrm{~g} \mathrm{C} \mathrm{kg}$ & $55.2,29.8,15.1,9.6$ & $65.2,36.5,27.7,22.7$ \\
Mineral soil, N stocks & $0-5,5-10,10-20,20-40 \mathrm{~cm}$ & $\mathrm{~g} \mathrm{~N} \mathrm{~kg}^{-1}$ & $4.3,2.5,1.2,0.8$ & $4.8,3.1,2.2,2.0$ \\
Mineral soil, C:N ratio & $0-5,5-10,10-20,20-40 \mathrm{~cm}$ & & $12.9,11.9,12.2,12.0$ & $13.5,11.9,12.4,11.5$ \\
Mineral soil, pH & $0-5,5-10 \mathrm{~cm}$ & & $3.6,3.9$ & $4.7,4.3$ \\
\hline
\end{tabular}

2, 703-723, 2005

$\mathrm{NO}$ and $\mathrm{NO}_{2}$ emission from Hungarian forest soils

L. Horváth et al.

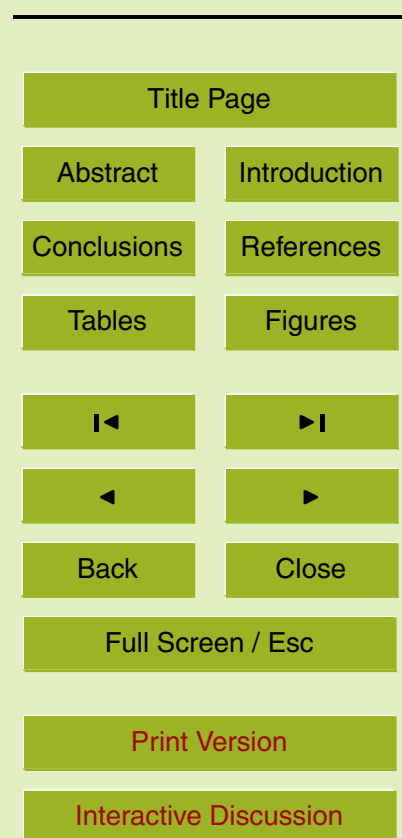

EGU 
Table 2. Monthly and yearly means of $\mathrm{NO}$ and $\mathrm{N}_{2} \mathrm{O}$ fluxes.

\begin{tabular}{lcccc}
\hline & \multicolumn{3}{c}{ flux $\left(\mu \mathrm{g} \mathrm{N}^{-2} \mathrm{~h}^{-1}\right)$} \\
\hline period & \multicolumn{2}{c}{ spruce } & \multicolumn{2}{c}{ oak } \\
\hline & $\mathrm{NO}$ & $\mathrm{N}_{2} \mathrm{O}$ & $\mathrm{NO}$ & $\mathrm{N}_{2} \mathrm{O}$ \\
\hline October, 2002 & 0.94 & 35.2 & n.a. & 36.0 \\
November, 2002 & 1.21 & 18.1 & n.a. & 4.7 \\
December, 2002 & 0.63 & 2.6 & n.a. & 2.0 \\
January, 2003 & $0^{* *}$ & 3.7 & n.a. & 1.1 \\
February, 2003 & $0^{* *}$ & $0^{* *}$ & n.a. & $0^{* *}$ \\
March, 2003 & $0^{* *}$ & $0^{* *}$ & n.a. & 30.9 \\
April, 2003 & 1.04 & 4.0 & n.a. & 5.7 \\
May, 2003 & 1.17 & 11.3 & 3.10 & 16.8 \\
June, 2003 & 0.99 & 14.9 & 2.13 & 28.6 \\
July, 2003 & 5.66 & 22.5 & n.a. & 35.8 \\
August, 2003 & 1.23 & 36.5 & n.a. & 48.9 \\
September, 2003 & 1.59 & 28.2 & 1.31 & 32.8 \\
\hline mean & 1.20 & 14.8 & $2.09^{*}$ & 20.3
\end{tabular}

$\mathrm{NO}$ and $\mathrm{NO}_{2}$ emission from Hungarian forest soils

L. Horváth et al.

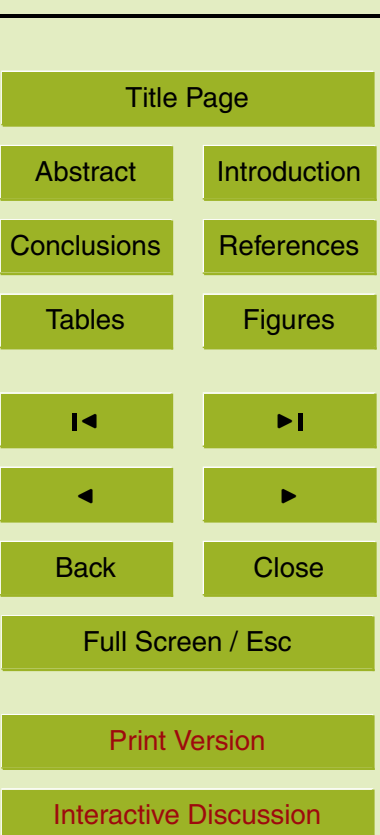

* Estimated from the ratio of spruce/oak fluxes from 3 months where data were available for both stations (mean of May, June, September for spruce: 1.25 , for oak: 2.18 , ratio=1.744)

${ }^{* *}$ Estimated (snow cover on soil) 
$\mathrm{NO}$ and $\mathrm{NO}_{2}$ emission from Hungarian forest soils

L. Horváth et al.

Table 3. Correlation ( $\mathrm{r}$ ) of $\mathrm{N}_{2} \mathrm{O}$ flux with soil temperature and moisture and with $\mathrm{NO}$ flux. All relationships are significant at $P=0.05$. NS $=$ not significant.

\begin{tabular}{cccccccc}
\hline & NO emission & $\mathrm{t}_{\text {soil }} 5 \mathrm{~cm}$ & $\mathrm{t}_{\text {soil }} 10 \mathrm{~cm}$ & $\mathrm{t}_{\text {soil }} 20 \mathrm{~cm}$ & $\mathrm{w}_{\text {soil }} 5 \mathrm{~cm}$ & $\mathrm{w}_{\text {soil }} 10 \mathrm{~cm}$ & $\mathrm{w}_{\text {soil }} 20 \mathrm{~cm}$ \\
\hline spruce & 0.40 & 0.45 & 0.67 & 0.67 & & & $\mathrm{NS}$ \\
oak & & 0.66 & 0.64 & 0.72 & -0.63 & -0.68 & -0.67
\end{tabular}

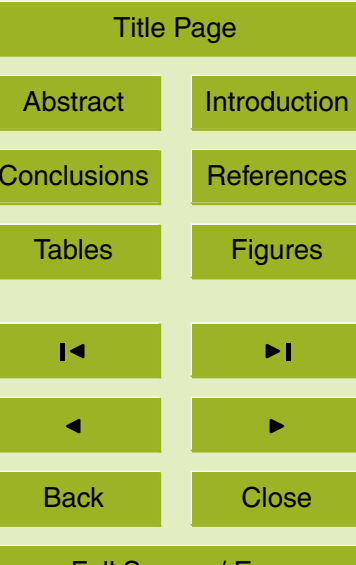

Full Screen / Esc

Print Version

Interactive Discussion 
Table 4. Atmospheric deposition and emission of nitrogen compounds at the spruce and oak stands.

\begin{tabular}{|c|c|c|c|c|c|c|}
\hline Site & Spruce & Oak & Spruce & Oak & Spruce & Oak \\
\hline Deposition (2001-2003) & \multicolumn{2}{|c|}{ Nitrate $\left(\mathrm{NO}_{3}^{-}\right)$} & \multicolumn{2}{|c|}{ Ammonium $\left(\mathrm{NH}_{4}^{+}\right)$} & \multicolumn{2}{|c|}{ Total N } \\
\hline & \multicolumn{6}{|c|}{$\left(\mathrm{gNm}^{-2} \mathrm{yr}^{-1}\right)$} \\
\hline Atmospheric wet deposition to the canopy (WD) & 0.25 & 0.25 & 0.29 & 0.29 & 0.54 & 0.54 \\
\hline Atmospheric dry deposition to the canopy $(\mathrm{DD})^{*}$ & 0.56 & 0.56 & 0.60 & 0.60 & 1.16 & 1.16 \\
\hline Throughfall deposition ${ }^{* *}$ (TF) & 0.49 & 0.31 & 0.85 & 1.01 & 1.34 & 1.32 \\
\hline Stemflow deposition ${ }^{* *}(\mathrm{SF})$ & 0.02 & 0.08 & 0.06 & 0.19 & 0.08 & 0.27 \\
\hline Atmospheric deposition to the soil (TF+SF) & 0.51 & 0.39 & 0.91 & 1.20 & 1.42 & 1.59 \\
\hline Atmospheric dry deposition to the soil (TF+SF-WD=DD-NCE) & \multirow[t]{6}{*}{0.26} & 0.14 & \multirow[t]{6}{*}{0.62} & \multirow[t]{6}{*}{0.91} & 0.88 & 1.05 \\
\hline Net canopy exchange (NCE=WD+DD-TF-SF) & & & & & 0.28 & 0.11 \\
\hline Total atmospheric deposition to the canopy (WD+DD=TF+SF+NCE) & & & & & 1.70 & 1.70 \\
\hline NCE as $\%$ of total $N$ deposition & & & & & $16 \%$ & $6.5 \%$ \\
\hline Litter fall deposition* $(\mathrm{LF})$ & & & & & 4.77 & 9.12 \\
\hline Total deposition to the soil (TF+SF+LF) & & & & & 6.19 & 10.7 \\
\hline Emission & \multicolumn{2}{|c|}{ Nitrous oxide $\left(\mathrm{N}_{2} \mathrm{O}\right)$} & \multicolumn{2}{|c|}{ Nitric oxide (NO) } & \multicolumn{2}{|c|}{ Total $\mathrm{N}$} \\
\hline \multirow[t]{2}{*}{ soil emission (SE) } & 0.13 & 0.18 & 0.011 & 0.018 & 0.14 & 0.20 \\
\hline & \multicolumn{6}{|c|}{$\left(\mathrm{gNm}^{-2} \mathrm{yr}^{-1}\right)$} \\
\hline soil emission/atmospheric deposition to the soil ( & & & & & $10 \%$ & \\
\hline
\end{tabular}

* estimated from Horváth (2004) following measurements between 1996-98 in spruce, assuming the same dry deposition rate for oak and spruce sites

${ }^{* *}$ courtesy of Miklós Manninger and Judit Sitkey, Forest Research Institute, Hungary

\section{$\mathrm{NO}$ and $\mathrm{NO}_{2}$ emission from Hungarian forest soils}

L. Horváth et al.

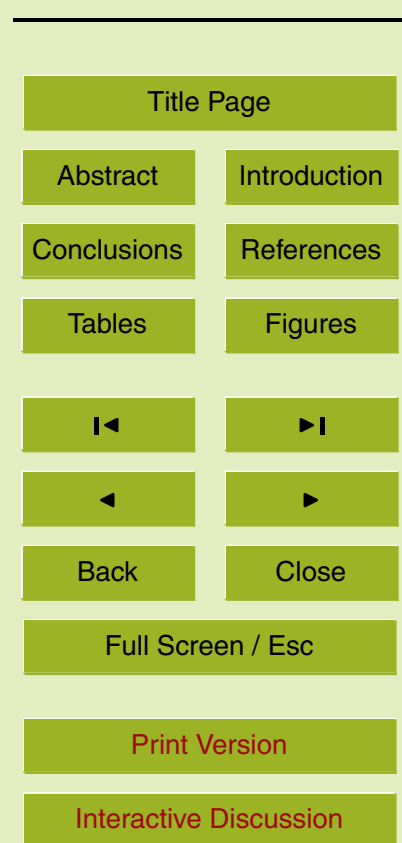

EGU 


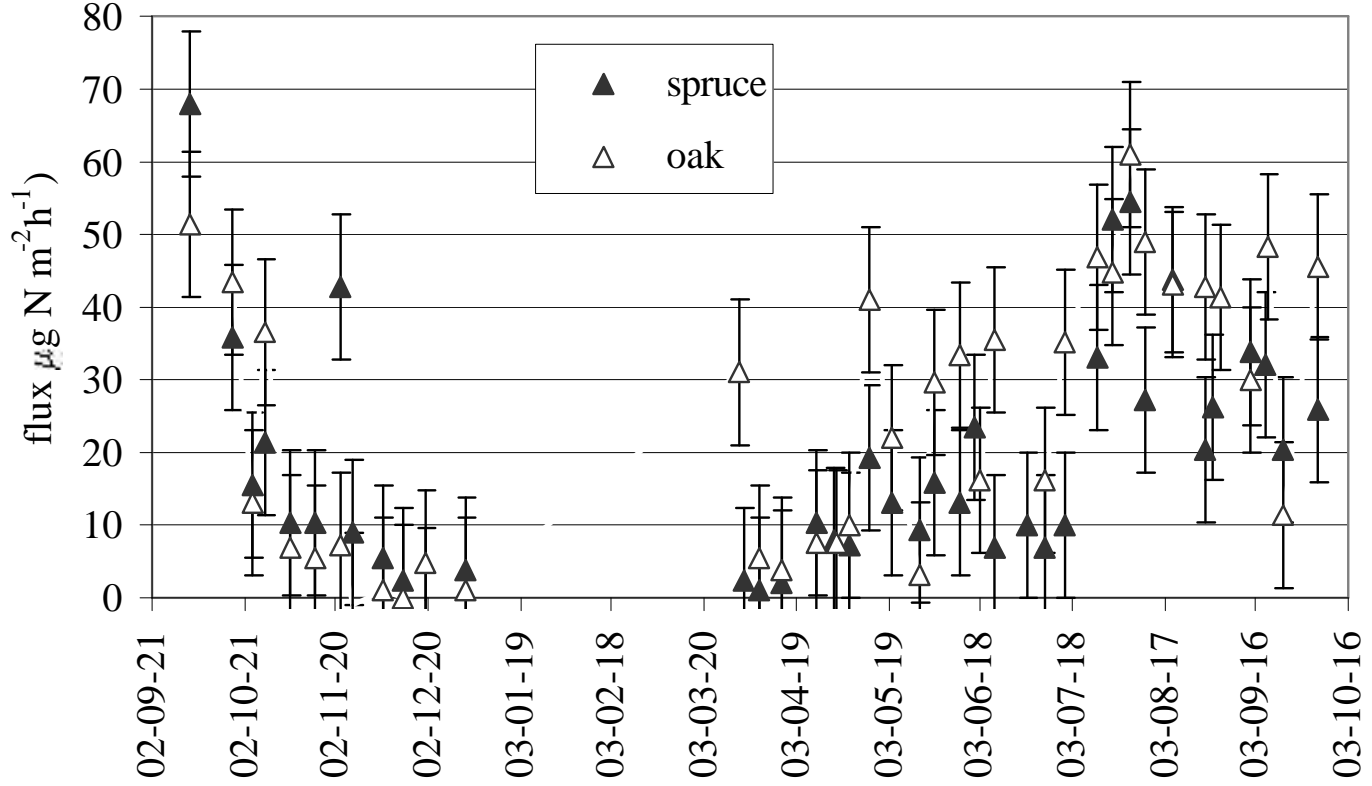

Fig. 1. $\mathrm{N}_{2} \mathrm{O}$ soil emission flux (mean of 8-8 chambers) error bars represent the $10 \%$ bulk error (CV) of sampling and measurement.
$\mathrm{NO}$ and $\mathrm{NO}_{2}$ emission from Hungarian forest soils

L. Horváth et al.

\section{Title Page}

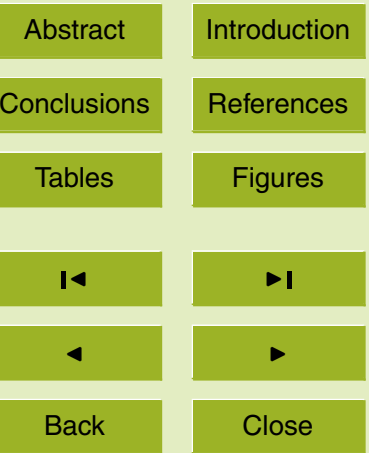

Full Screen / Esc

Print Version

Interactive Discussion 
BGD

2, 703-723, 2005

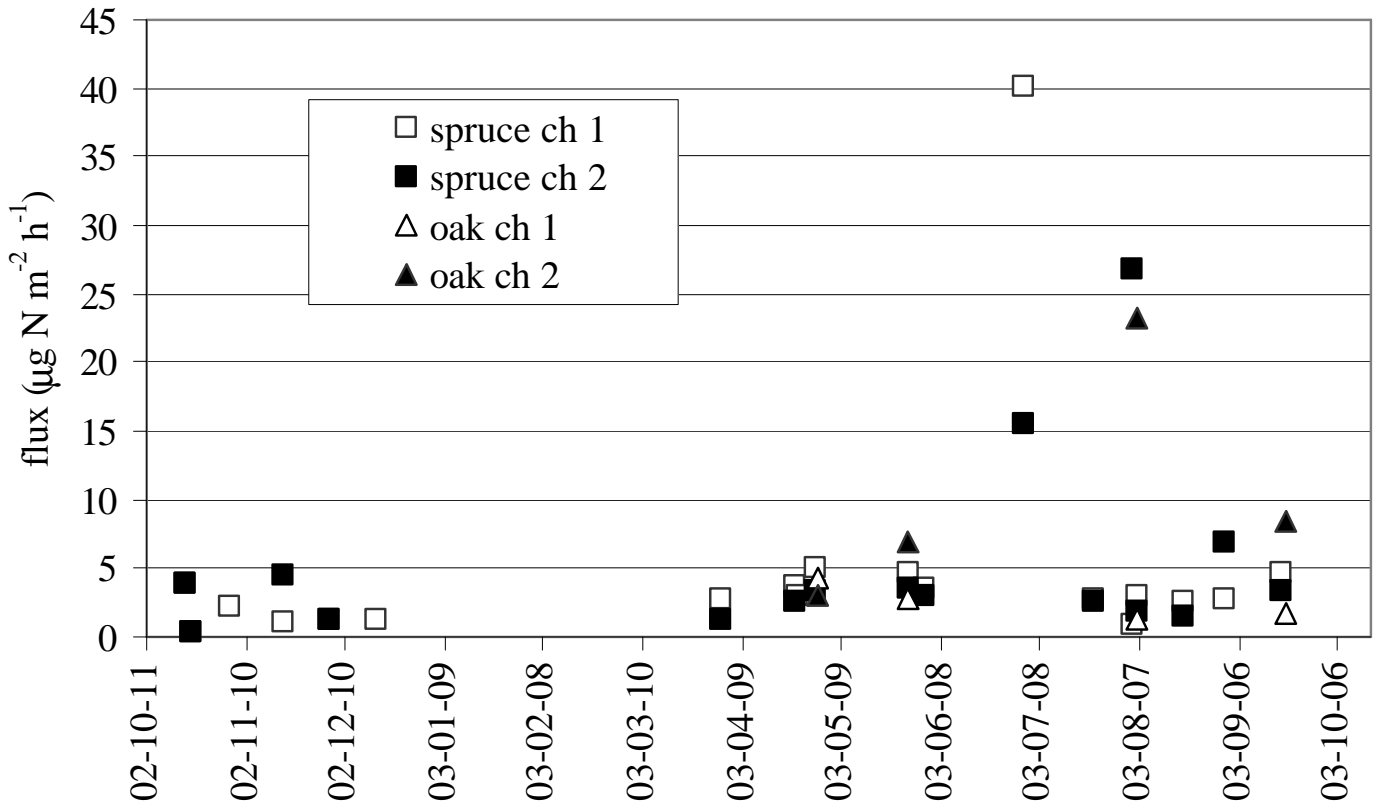

$\mathrm{NO}$ and $\mathrm{NO}_{2}$ emission from Hungarian forest soils

L. Horváth et al.

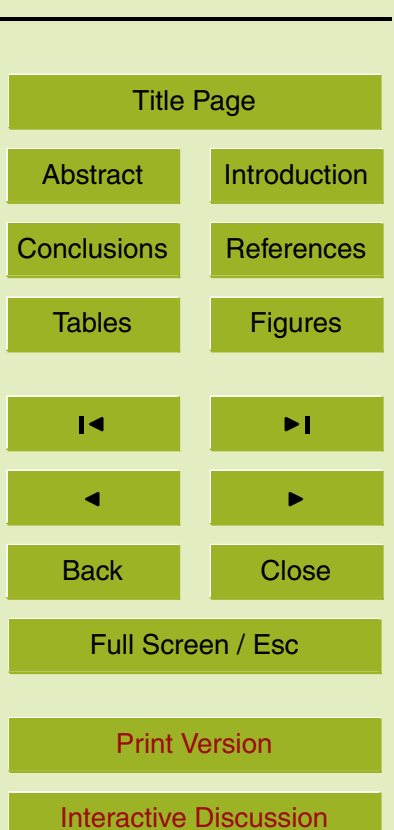

EGU 